\title{
GASTRECTOMY IN OCTOGENARIANS WITH GASTRIC CANCER: IS IT
} FEASIBLE?

\author{
Gastrectomia em octogenários com câncer gástrico: ela é factível? \\ Francisco Diogo Almeida SILVA ${ }^{1 \oplus}$, Marina Alessandra PEREIRA ${ }^{2 \oplus}$, Marcus Fernando Kodama Pertille RAMOS ${ }^{2}$, $_{\text {, }}$ \\ Ulysses RIBEIRO-JUNIOR ${ }^{2 \oplus}$, Bruno ZILBERSTEIN ${ }^{2}{ }^{\oplus}$ Ivan CECCONELLO $^{2 \oplus}{ }^{\circ}$ Andre Roncon DIAS ${ }^{2}$
}

\begin{abstract}
Background: The octogenarian population is expanding worldwide and demand for gastrectomy due to gastric cancer in this population is expected to grow. However, the outcomes of surgery with curative intent in this age group are poorly reported and it is unclear what matters most to survival: age, clinical status, disease's stage, or the extent of the surgery performed. Aim: Evaluate the results of gastrectomy in octogenarians with gastric cancer and to verify the factors related to survival. Methods: From prospective database, patients aged 80 years or older with histologically confirmed adenocarcinoma who had undergone gastrectomy with curative intent were selected. Factors related to postoperative complications and survival were studied. Results: Fifty-one patients fulfilled the inclusion criteria. A total of 70.5\% received subtotal gastrectomy and in 72.5\% D1 lymphadenectomy was performed. Twenty-five (49\%) had complications, in eleven major complications occurred (seven of these were clinical complications). Hospital length of stay was longer (8.5 vs. 17.8 days, $p=0.002$ ), and overall survival shorter (median of 1.4 vs. 20.5 months, $p=0.009$ ) for those with complications. D2 lymphadenectomy and the presence of postoperative complications were independent factors for worse overall survival. Conclusion: Octogenarians undergoing gastrectomy with curative intent have high risk for postoperative clinical complications. D1 lymphadenectomy should be the standard of care in these patients.

HEADINGS: Stomach neoplasms. Gastrectomy. Aged, 80 and over. Aged._Survival.
\end{abstract}

RESUMO - Racional: A população octogenária está expandindo mundialmente e é esperado que a demanda por gastrectomia devido a câncer gástrico nessa faixa também aumente. Entretanto, os resultados da operação curativa nessa população são pobremente reportados e não está claro o que mais importa no resultado: idade, status clínico, estágio da doença, ou a extensão da operação. Objetivos: Avaliar os resultados cirúrgicos da gastrectomia em octogenários e verificar os fatores relacionados com a sobrevida. Métodos: Através de revisão de banco de dados prospectivo, pacientes com 80 anos ou mais de idade e adenocarcinoma gástrico comprovado histologicamente e submetidos a gastrectomia com intuito curativo foram analisados. Fatores relacionados a complicações pós-operatórias e sobrevida foram estudadas. Resultados: Cinquenta e um pacientes preencheram os critérios de inclusão. A gastrectomia subtotal foi realizada em $70,5 \%$ dos casos e a linfadenectomia D1 em 72,5\% dos pacientes. Complicações ocorreram em 25 pacientes (49\%), sendo que em 11 elas foram graves (sete foram complicações clínicas). Pacientes com complicações tiveram maior duração da internação hospitalar $(8,5$ vs. 17,8 dias, $p=0,002)$ e sobrevida global mais curta (mediana de 1,4 vs. 20,5 meses, $p=0,009$ ). Linfadenectomia D2 e a presença de complicações foram fatores independentes de pior sobrevida global. Conclusão: Os octogenários submetidos à gastrectomia com intenção curativa apresentam alto risco de complicações clínicas no pós-operatório. A linfadenectomia D1 deve ser o padrão de atendimento nesses pacientes.

DESCRITORES: Neoplasias gástricas. Gastrectomia. Idoso. Idoso de 80 anos ou mais. Sobrevida.

\begin{tabular}{l} 
Central message \\
\hline Gastric cancer octogenarians undergoing \\
gastrectomy with curative intent have high risk \\
for postoperative clinical complications. D1 \\
lymphadenectomy should be the standard of care in \\
these patients.
\end{tabular}

\section{Perspective}

The present study considered an unbiased population of gastric cancer octogenarians considered fit for potentially curative gastrectomy. They had increased risk for clinical complications. D2 lymphadenectomy and the occurrence of complications correlated with worse overall survival. Further studies should aim in the age limit to refrain from extended lymphadenectomy.

From the ${ }^{1}$ Faculdade de Ciências Médicas de Campina Grande, Medicina, Campina Grande, PB, Brasil; ${ }^{2}$ Hospital de Clínicas, Faculdade de Medicina, Universidade de São Paulo, Instituto do Câncer, São Paulo, SP, Brasil ('Faculty of Medical Sciences of Campina Grande, Medicine, Campina Grande, PB, Brazil; ${ }^{2}$ Hospital de Clínicas, Faculty of Medicine, University of São Paulo, Cancer Institute, São Paulo, SP, Brazil)

How to cite this article: Silva FDA, Pereira MA, Ramos MFKP, Ribeiro-Junior U, Zilberstein U, Cecconello I, Dias AR. Gastrectomy in octogenarians with gastric cancer: is it feasible? ABCD Arq Bras Cir Dig. 2020;33(4):e1552. DOI: /10.1590/0102-672020200004e1552

\section{Correspondence:}

Andre Roncon Dias

Email: roncon86@hotmail.com

andre.dias@hc.fm.usp.br
Financial source: none

Conflict of interest: none

Received for publication: 06/06/2020

Accepted for publication:20/09/2020 
INTRODUCTION

G astric cancer is one of the leading causes of cancer-related mortality worldwide ${ }^{10,21}$. As most cases are diagnosed in the $7^{\text {th }}$ decade of life ${ }^{4}$ and life expectancy is increasing, demand for gastrectomy in the very older patients will rise ${ }^{19,21}$. Octogenarians are a particular group of interest. They are an expanding population, frequently frail or with comorbidities. Also, their complication rate is expected to be higher and survival shorter when compared to younger patients $8,13,20$. At this moment it is unclear what matters most to survival: age, preoperative clinical status, the disease's stage, or the extent of the surgery performed. Is D2 lymphadenectomy adequate for octogenarians? All these topics remain poorly investigated.

This study aimed to evaluate the results of gastrectomy in octogenarians with gastric cancer and to verify the factors related to low survival.

\section{METHODS}

This study was approved by the hospital ethics committee and is registered online (www.plataformabrasil.com; CAAE: 30308620.1.0000.0068)

\section{Patient population and study design}

All patients who underwent any surgical procedure for gastric cancer between 2009 and 2019 were retrospectively evaluated. Data were obtained from a prospective medical database. Eligible patients were those aged 80 years or older, with histologically confirmed adenocarcinoma and submitted to gastrectomy with curative intent. Exclusion criteria included palliative surgery and procedures performed in urgency/emergency setting.

Comorbidities were evaluated by the Charlson comorbidity index and surgical complications were graded according to Clavien-Dindo (> 2 was considered as major complication $)^{6}$. Deaths until 30 days after the gastrectomy or during the postoperative stay were considered as surgical mortality.

The surgical procedure was performed as recommended by the Japanese Gastric Cancer Association? ${ }^{7}$.Tumor was staged according to the $8^{\text {th }}$ TNM edition ${ }^{1}$.

Patients were divided into two groups: with and without postoperative complications (POC). Complications were classified as clinical or surgical (those directly related to the procedure).

\section{Statistical analysis}

Nominal data are presented in frequencies with percentages and numerical data in means with standard deviation. Continuous and categorical variables were analyzed by t-test and squared-chi test, respectively. A receiver operating characteristic (ROC) curve was used to determine the better cutoff value for tumor size that correlated with death. The area under the ROC curve (AUC) was employed as a measure of accuracy. Survival was calculated from the date of surgery until the event (death/ relapse) or last follow-up and estimated using the KaplanMeier method; the log-rank test was used to evaluate the difference between the curves. Overall survival (OS) was calculated until death and disease-free survival until the date of disease recurrence. Multivariate Cox proportional hazard analysis was performed to analyze the prognostic factors related to survival. Hazard ratio and $95 \%$ confidence interval were calculated as a measurement of association. All $p$ values were reported as two-tailed and a $p$-value of 0.05 or less was considered statistically significant. Analyses were performed using the SPSS program (Version 20; SPSS, Chicago, IL, USA).

\section{RESULTS}

In the period considered, from 1,156 patients operated, 91 were octogenarians (7.8\%) and 51 fulfilled the inclusion criteria. Most patients were males (72.5\%) and the mean age was 84 years old (range $80-94$ ). Subtotal gastrectomy was performed in $70.5 \%$ of the cases and $72.5 \%$ had D1 lymphadenectomy. The mean number of lymph nodes retrieved was 35 . The mean tumor size was $4.9 \mathrm{~cm}( \pm 2.5)$. The ROC curve determined the cut-off of $4.9 \mathrm{~cm}$ for lesion size associated with death $(A \cup C=70.7 \%, 95 \% \mathrm{Cl} 0.56-0.86$, $\mathrm{p}=0.012$ )

POC occurred in 24 (47\%) patients, eleven $(21.5 \%$ of the total) had major ones. Clinical POC were responsible for seven of the major complications and four (out of six) postoperative deaths.

Clinical and pathological characteristics of those with and without $\mathrm{POC}$ are presented in Table 1. Age, gender, Charlson index, ASA, and TNM stage were similar between groups; lymphatic and venous invasion were more frequent in the POC group. Hospital length of stay was higher in the POC group (8.5 vs. 17.8 days, $p=0.002)$.

\section{Survival outcomes}

In a median follow-up of eighteen months, 27 (53\%) patients died, and eleven (21.5\%) had disease recurrence. Mortality in 30 and 90 days were $9.8 \%(n=5)$ and $15.7 \%(n=8)$. The median OS for all patients was 24.1 months. Disease-free survival and OS curves are presented in Figure 1.
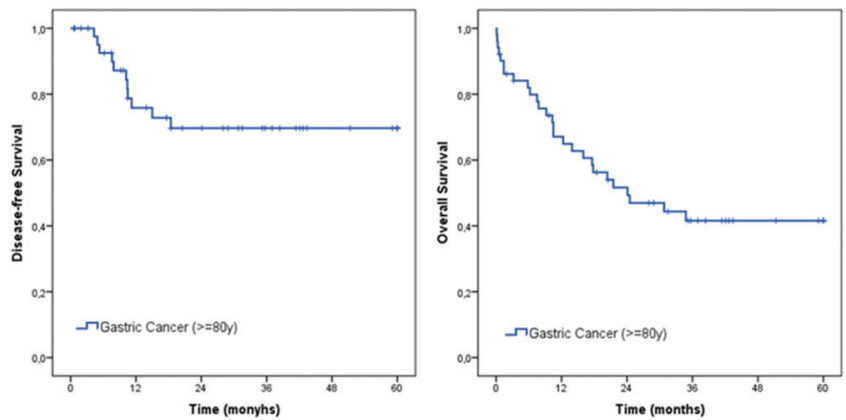

FIGURE 1 - Overall survival and disease-free survival for gastric cancer octogenarians

Regarding the type of lymphadenectomy, patients who underwent D1 y had better OS rates compared to D2 $(p=0.037)$. The median OS for D2 was 13.9 months (median not reached for D1, Figure $2 \mathrm{~A}$ ).

Considering the tumor size, patients with larger lesions $(\geq 4.9 \mathrm{~cm}$ ) had worse OS (median of 17.2 months - median not reached for smaller lesions, $p=0.015$, Figure $2 B$ ).

Survival was different according to the occurrence of surgical complications $(p=0.009)$. The median OS for patients with major-POC and minor-POC was 1.4 and 20.5 months, respectively (Figure $2 \mathrm{C}$ ). Concerning the non-POC group as reference, patients with minor-POC had lower survival $(p=0.120)$, followed by those with major-POC $(p=0.003)$

When stratified by PTNM, the OS was significantly different between stages I, II, and III $(p=0.006)$. The median OS for stages II and III were 24.1 and 10.5 months, respectively (Figure 2D).

At multivariate analysis, D2 lymphadenectomy, and the presence of POC were independent factors for worse OS (Table 2). 
TABLE 1 - Clinicopathological characteristics of gastric cancer octogenarians according to the presence or absence of postoperative complications (POC)

\begin{tabular}{|c|c|c|c|}
\hline & non-POC & $\mathrm{POC}$ & \\
\hline Variables & $n=27$ & $n=24$ & $p$ \\
\hline Gender & & & 0.104 \\
\hline Female & $10(37)$ & $4(16.7)$ & \\
\hline Male & $17(63)$ & $20(83.3)$ & \\
\hline Age (years) & & & 0.843 \\
\hline Mean (SD) & $83.9(2.7)$ & $84.1(3.8)$ & \\
\hline $\mathrm{BMI}\left(\mathrm{Kg} / \mathrm{cm}^{2}\right)$ & & & 0.670 \\
\hline Mean (SD) & $23.7(3.8)$ & $23.3(3.5)$ & \\
\hline Hemoglobin & & & 0.063 \\
\hline Mean (SD) & $12.1(2.0)$ & $10.8(2.1)$ & \\
\hline Neutrophil lymphocyte ratio (NLR) & & & 0.715 \\
\hline Mean (SD) & $3.11(3.17)$ & $2.78(1.99)$ & \\
\hline \multicolumn{2}{|c|}{ Charlson-Deyo Comorbidity Index (CCl) } & & 0.842 \\
\hline 0 & $15.6(55.6)$ & $14(58.3)$ & \\
\hline$\geq 1$ & $12(44.4)$ & $10(41.7)$ & \\
\hline \multicolumn{2}{|c|}{ American Society of Anesthesiologists (ASA) } & & 0.593 \\
\hline II & $18(66.7)$ & $14(58.3)$ & \\
\hline III & $9(33.3)$ & $10(41.7)$ & \\
\hline Type of surgery & & & 0.232 \\
\hline Subtotal & $21(77.8)$ & $15(62.5)$ & \\
\hline Total & $6(22.2)$ & 9 (37.5) & \\
\hline Type of lymphadenectomy & & & 0.318 \\
\hline D1 & $18(66.7)$ & 19 (79.2) & \\
\hline D2 & $9(33.3)$ & $5(20.8)$ & \\
\hline Tumor site & & & 0.267 \\
\hline Lower & $20(74.1)$ & $14(58.3)$ & \\
\hline Middle & $6(22.2)$ & $6(25)$ & \\
\hline Upper & $1(3.7)$ & $1(4.2)$ & \\
\hline Stump & $0(0)$ & $3(12.5)$ & \\
\hline Tumor size & & & 0.781 \\
\hline Smaller $(<4.9 \mathrm{~cm})$ & $14(51.9)$ & $11(45.8)$ & \\
\hline Larger & $12(48.1)$ & $13(54.2)$ & \\
\hline Lauren type & & & 0.570 \\
\hline Intestinal & $21(77.8)$ & $17(70.8)$ & \\
\hline Diffuse/mixed & $6(22.2)$ & $7(29.2)$ & \\
\hline Histological grade & & & 0.552 \\
\hline Well / moderately differentiated & $19(70.4)$ & $15(62.5)$ & \\
\hline Poorly differentiated & $8(29.6)$ & $9(37.5)$ & \\
\hline Lymphatic invasion & & & 0.016 \\
\hline No & $17(63)$ & 7 (29.2) & \\
\hline Yes & $10(37)$ & $17(70.8)$ & \\
\hline Venous invasion & & & 0.038 \\
\hline No & $21(77.8)$ & $12(50)$ & \\
\hline Yes & $6(22.2)$ & $12(50)$ & \\
\hline Perineural Invasion & & & 0.507 \\
\hline No & $16(59.3)$ & $12(50)$ & \\
\hline Yes & $11(40.7)$ & $12(50)$ & \\
\hline $\mathrm{N}^{\circ} \mathrm{LNs}$ & & & 0.947 \\
\hline Mean (SD) & $34.9(17.6)$ & $35.3(20.1)$ & \\
\hline pT & & & 0.388 \\
\hline $\mathrm{T} 1 / \mathrm{T} 2$ & $11(40.7)$ & $7(29.2)$ & \\
\hline $\mathrm{T} 3 / \mathrm{T} 4$ & $16(59.3)$ & $17(70.8)$ & \\
\hline $\mathrm{pN}$ & & & 0.100 \\
\hline NO & 14 (51.9) & $7(29.2)$ & \\
\hline $\mathrm{N}+$ & $13(48.1)$ & $17(79.8)$ & \\
\hline pTNM & & & 0.645 \\
\hline I & $9(33.3)$ & $7(29.2)$ & \\
\hline II & $9(33.3)$ & $6(25)$ & \\
\hline III & $9(33.3)$ & $11(45.8)$ & \\
\hline Postoperative complication (POC) & & & na \\
\hline No POC & $27(0)$ & $0(0)$ & \\
\hline Minor POC & $0(0)$ & $13(54.2)$ & \\
\hline Major POC & $0(0)$ & $11(45.8)$ & \\
\hline Chemotherapy & & & 1.0 \\
\hline No & 25 (92.6) & 22 (91.7) & \\
\hline Yes & $2(7.4)$ & $2(8.3)$ & \\
\hline
\end{tabular}

$\mathrm{SD}=$ standard deviation; $\mathrm{p}$-values in bold are statistically significant
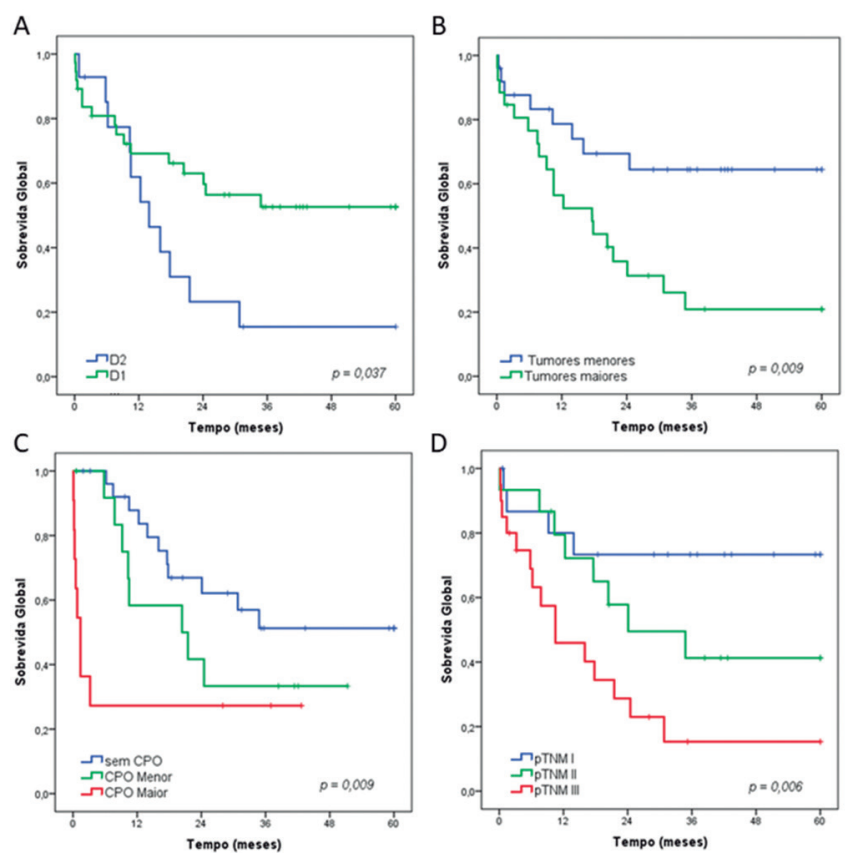

FIGURE 2 - Overall survival for gastric cancer octogenarians according to: A) type of lymphadenectomy performed (D1 vs. D2); B) tumor size (< vs. $\geq 4.9 \mathrm{~cm}$ ); C) Postoperative complications (absent vs. minor vs. major); D) TNM stage (I vs. II vs. III).

TABLE 2 - Univariate and multivariate analysis for overall survival

\begin{tabular}{|c|c|c|c|c|c|c|}
\hline Overall survival & & $\begin{array}{l}\text { nivariate } \\
\text { analysis }\end{array}$ & & & $\begin{array}{l}\text { ultivariate } \\
\text { analysis }\end{array}$ & \\
\hline Variables & HR & $95 \% \mathrm{Cl}$ & $\mathrm{p}$ & HR & $95 \% \mathrm{Cl}$ & $\mathrm{p}$ \\
\hline Male (vs. female) & 1.05 & $0.45-2.49$ & 0.906 & - & - & - \\
\hline ASA III (vs. ASA II) & 1.44 & $0.67-3.11$ & 0.354 & - & - & - \\
\hline $\begin{array}{c}\text { Charlson > } 1 \text { (vs. } \\
\text { Charlson 0) }\end{array}$ & 0.79 & $0.36-1.73$ & 0.560 & - & - & - \\
\hline $\begin{array}{l}\text { Total gastrectomy } \\
\text { (vs. subtotal) }\end{array}$ & 0.89 & $0.39-2.04$ & 0.785 & - & - & - \\
\hline D2 (vs. D1) & 2.25 & $1.03-4.91$ & 0.042 & 3.53 & $1.41-8.83$ & 0.007 \\
\hline $\begin{array}{l}\text { Large tumor } \\
(\geq 4.9 \mathrm{~cm})(\mathrm{vs} \\
\text { smaller) }\end{array}$ & 2.70 & $1.18-6.20$ & 0.019 & 1.96 & $0.74-5.23$ & 0.178 \\
\hline pN+ (vs. pN0) & 1.82 & $0.81-4.06$ & 0.144 & - & - & - \\
\hline pT3/T4 (vs T1/T2) & 3.98 & $\begin{array}{l}1.37- \\
11.52\end{array}$ & 0.011 & 2.29 & $0.66-7.89$ & 0.191 \\
\hline $\begin{array}{l}\text { Major POC (vs. } \\
\text { non/minor POC) }\end{array}$ & 3.17 & $1.37-7.31$ & 0.007 & 1.19 & $1.93-13.95$ & 0.001 \\
\hline
\end{tabular}

\section{DISCUSSION}

Gastrectomy outcomes in octogenarians are a debatable matter with data coming from the small and unicentric retrospective series ${ }^{21}$. In our cohort, gastric cancer octogenarians undergoing surgery with curative intent were usually submitted to subtotal gastrectomy and received D1 lymphadenectomy. Complications were frequent (47\%) a higher when compared to series with younger patients ${ }^{16,17}$. Major complications occurred in $21.5 \%$ of the patients and were usually due to clinical ones, which is similar to what other authors observed $2,11,12,14$. Patients with POC had longer hospital length of stay and shorter OS. Major complications were a significant predictor of poor survival.

Patients with lesions $\geq 4.9 \mathrm{~cm}$ also had worse OS, size has been implicated as a predictor of survival by other authors as well ${ }^{9,18,22}$. D2 lymphadenectomy was an independent risk factor for shorter survival with a hazard ratio of 3.53. Although 
D2 is indicated for advanced gastric cancer ${ }^{23}$, it also carries an increased risk for complications, and since octogenarians are already frail, with comorbidities and have a short life expectancy, a quicker and less oncological procedure (D1) is better ${ }^{8,21}$. In fact, D1 in frail patients is already very morbid ${ }^{12}$. Additionally, in our cohort, the presence of lymph node metastasis was not a factor associated with survival, which reinforces that restricted lymphadenectomy is appropriate in these patients. In our opinion, omentectomy may also be neglected in these patients ${ }^{3}$.

Clinical parameters expected to impair survival (ASA, Charlson index) were not significant at univariate analysis, probably because this is a selected cohort of patients. Octogenarians with unfavorable conditions were not indicated for surgery with curative intent. Additionally, total gastrectomy was not associated with worst outcomes (when compared to subtotal) and it may be due to a small number of cases included, and there is again selection bias since distal and less morbid surgery was preferred for octogenarians.

It is worth mentioning that the number of lymph nodes retrieved was high even for $D 1$. We credit this to the use of Carnoy's solution as a fixative and not contamination of D2 nodal stations in D1 patients ${ }^{5}$

The present study has the limitations of its retrospective nature. On the other hand, it presents a population considered fit for curative surgery, preventing bias in the survival analysis.

\section{CONCLUSION}

Octogenarians undergoing gastrectomy with curative intent have a high risk of postoperative clinical complications. D2 lymphadenectomy and the occurrence of major complications were independent risk factors associated with worse survival. D1 lymphadenectomy should be the standard in these patients.

\section{REFERENCES}

1. Ajani JA, In H, Sano T, Gaspar LE, Erasmus JJ, Tang LH, et al. American Joint Committee on Cancer (AJCC). Cancer Staging Manual. 8th edition. Stomach. Springer 2017; 17:203 - 220.

2. Andreollo NA, Drizlionoks E, Tercioti-Junior V, Coelho-Neto JS, Ferrer JAP, Carvalheira JBC, et al. Adjuvant chemoradiotherapy after subtotal or total gastrectomy and D2 limphadenectomy increases survival in advanced gastric cancer? ABCD, arq. bras. cir. dig., 2019, vol.32, no.4. ISSN 0102-6720

3. Barchi LC, Ramos MFKP, Dias AR, et al. Total omentectomy in gastric cancer surgery: is it always necessary?.Arq Bras Cir Dig.2019;32(1):e1425.

4. Cancer.net. Stomach Cancer: Statistics. Available at: www.cancer.net/ cancer-types/stomach-cancer/statistics. Accessed: january 23rd 2020.

5. Dias AR, Pereira MA, Mello ES, Zilberstein B, Cecconello I, Ribeiro Junior $U$. Carnoy's solution increases the number of examined lymph nodes following gastrectomy for adenocarcinoma: a randomized trial. Gastric Cancer.2016;19(1):136-142.https://doi.org/10.1007/s10120-014-0443-2
6. DindoD, Demartines N, ClavienPA.Classification of surgicalcomplications: a new proposal with evaluation in a cohort of 6336 patients and results of a survey. Ann Surg. 2004;240(2):205-213. https://doi.org/10.1097/01. sla.0000133083.54934.ae

7. Japanese Gastric Cancer Association. Japanese gastric cancer treatment guidelines 2014 (ver. 4). Gastric Cancer. 2017;20(1):1-19. https://doi. org/10.1007/s10120-016-0622-4

8. $\mathrm{KimJ}, \mathrm{ChinHM}$,JunKH.Surgical outcomesand survival aftergastrectomy in octogenarians with gastric cancer. J Surg Res. 2015;198(1):80-86. https://doi.org/10.1016/j.jss.2015.05

9. Liu $X, X u Y$, Long Z, Zhu H, Wang Y. Prognostic significance of tumor size in T3 gastric cancer. Ann Surg Oncol. 2009;16(7):1875-1882. https:// doi.org/10.1245/s10434-009-0449-X

10. Luo G, Zhang Y, Guo P, Wang L, Huang Y, Li K. Global patterns and trends in stomach cancer incidence: Age, period and birth cohort analysis. Int J Cancer. 2017;141(7):1333-1344. https://doi.org/10.1002/ijc.30835

11. Mikami J, Kurokawa Y, Miyazaki Y, Takahashi T, Yamasaki M, Miyata H, et al. Postoperative gastrectomy outcomes in octogenarians with gastric cancer. Surg Today. 2015;45(9):1134-1138. https://doi.org/10.1007/ s00595-014-1087-x

12. Mita K, Ito H., Hashimoto M, Murabayashi R, Asakawa H, Nabetani M, et al. Postoperative complications and survival after gastric cancer surgery in patients over 80 years of age. J Gastrointest Surg. 2013;17(12):20672073. https://doi.org/10.1007/s11605-013-2364-5

13. Norero E, Quezada JL, Cerda J, Ceroni M, Martinez C, Mejía R, et al. Risk factors for severe postoperative complications after gastrectomy for gastric and esophagogastric junction cancers. $A B C D$, arq. bras. cir. dig., 2019, vol.32, no.4. ISSN 0102-6720

14. Ramos MFKP, Pereira MA, Charruf AZ, Dias AR, Castria TB, Barchi LC, et al. Conversion therapy for gastric cancer: expanding the treatment possibilities. ABCD, arq. bras. cir. dig., 2019, vol.32, no.2. ISSN 0102-6720

15. Ramos MFKP, Pereira MA, Dias AR, Yagi OZ, Zaidan EP, Ribeiro-Júnior U, et al. Surgical outcomes of gastrectomy with D1 lymph node dissection performed for patients with unfavorable clinical conditions. Eur J Surg Oncol. 2019;45(3):460-465. https://doi.org/10.1016/j.ejso.2018.11.013

16. Ramos MFKP, Pereira MA, Sagae VMT, Mester M, Morrell ALG, Dias $A R$, et al. Gastric cancer in young adults: a worse prognosis group? Rev Col Bras Cir. 2019;46(4):e20192256. https://doi.org/10.1590/01006991e-20192256

17. Ramos MFKP, Pereira MA, Yagi OK, Dias AR, Charruf AZ, Oliveira RJ, et al. Surgical treatment of gastric cancer: a 10-year experience in a highvolume university hospital. Clinics (Sao Paulo).2018;73(suppl 1): e543s. https://doi.org/10.6061/clinics/2018/e543s

18. Saito H, Osaki T, Murakami D, Sakamoto T, Kanaji S, Oro S, et al. Macroscopic tumor size as a simple prognostic indicator in patients with gastriccancer.AmJSurg.2006;192(3):296-300.https://doi.org/10.1016/j. amjsurg.2006.03.004

19. de Souza Giusti AC, de Oliveira Salvador PT, Dos Santos J, Meira KC, Camacho AR, Guimarães RM, et al. Trends and predictions for gastric cancer mortality in Brazil. World J Gastroenterol. 2016;22(28):6527-6538. https://doi.org/10.3748/wjg.v22.i28.6527

20. Takama T, Okano K, Kondo A, Akamoto S, Fujiwara M, Usuki H, et al. Predictors of postoperative complications in elderly and oldest old patients with gastric cancer. Gastric Cancer. 2015;18(3):653-661. https:// doi.org/10.1007/s10120-014-0387-6

21. Xu Y, Wang Y, Xi C, Ye N, Xu X. Is it safe to perform gastrectomy in gastric cancer patientsaged 80 orolder?:A meta-analysis and systematic review. Medicine (Baltimore). 2019; 98 (24):e16092. https://doi.org/10.1097/ MD.0000000000016092

22. Yokota T, Ishiyama S, Saito T, Teshima S, Yamada Y, Iwamoto K, et al. Is tumor size a prognostic indicator for gastric carcinoma?. Anticancer Res. 2002;22(6B):3673-3677.

23. Zilberstein B, Malheiros C, Gomes LL, et al. Brazilian consensus in gastric cancer: guidelines for gastric cancer in Brazil. $A B C D$, arq. bras. cir. dig. [online]. 2013, vol.26, n.1 